\title{
Emancipation Research in Information Systems: Integrating Agency, Dialogue, Inclusion, and Rationality Research
}

\author{
Amber G. Young \\ University of Arkansas \\ ayoung@walton.uark.edu
}

\author{
Yaping Zhu \\ University of Arkansas \\ yzhu@walton.uark.edu
}

\author{
Viswanath Venkatesh \\ University of Arkansas \\ vvenkatesh@vvenkatesh.us
}

\begin{abstract}
Emancipation is a key concept in critical theories. Prior work suggests that emancipation is a complex and multi-faceted concept. Many conceptualizations of emancipation exist, and emancipation is defined in different ways. Existing empirical studies mainly focus on one or few components of emancipation. To have an integrated understanding of emancipation, we review the literature on emancipation in information systems (IS), with a view toward developing a typology of components of emancipation in the IS field. The typology of emancipation components consists of four components: freedom to act, freedom to express, freedom to belong and freedom to think. These components relate to the concepts of agency, dialogue, inclusion, and rationality, respectively.
\end{abstract}

\section{Introduction}

Critical theories "facilitate clarification of the meaning of human need and expansion of autonomy in personal and social life" [1, p. 432]. These theories provide a lens for viewing the world in ways that challenge "social conditions and institutions and oppressive forms of control, often enabled and supported by IS, which prevent realization of humane, just and free organizations and society" [2, p. 442]. In the field of information systems (IS), critical theories have been applied to understanding of "social issues such as freedom, power, social control, and values with respect to the development, use, and impact of information technology" [3, p. 17].

A central concept in critical theories is emancipation. Emancipation has been defined a variety of ways by IS scholars, as shown in Table 1. Emancipation is an ideal state and the opposite of oppression. Emancipation is a complex concept encompassing "truth exposure, democratization, community enhancement, inclusion, creative expression, economic facilities, political liberties, and facilitation of social change" [4, p. 343]. This is by no means an exhaustive list of components of emancipation. Because emancipation is complex and multi-faceted, measuring emancipation for empirical research is challenging [5]. Thus, much empirical research on emancipation measures only one or few components of emancipation to keep the scope of the study manageable.

The objective of this research is to review the empirical literature on emancipation in IS, with the goal of identifying diverse streams of IS literature that relate to emancipation. We contend that much IS research on emancipation does not reference the meta-theory of emancipation from which it draws. Thus, we first seek to understand the components of emancipation studied by IS researchers. Then, future research may review the literature on each of these components to identify themes, commonalities, contradictions, and paradoxes related to emancipation. This manuscript presents a "specific theorizing review" [6, p. 555] developed using the hermeneutic approach for conducting a literature review [7].

This research highlights the lack of clarity regarding which streams of IS literature fall under the emancipation research umbrella. Because many emancipation studies are not tethered to a meta-theory, synthesis of this literature is challenging. We address this challenge by reviewing the literature on emancipation in IS, organizing the literature according to the component(s) of emancipation addressed, and outlining the next steps and research questions that can be pursued toward integration of emancipation research in IS.

We first present an overview of the literature on emancipation in IS. We then describe the methodology used for identifying relevant empirical studies. Finally, we provide a summary of our initial findings and discuss the future research needed to move emancipation research in IS forward.

\section{Literature Review}


Some management researchers reject the notion that emancipation applies to business research [8]. One could go as far as to say that theorizing about emancipation in relatively trivial business contexts offensively minimizes the very real suffering of those seeking emancipation from horrendous oppression such as slavery or colonization. Yet, such a hard-lined stance against critical research in business contexts ignores the value of "softer" approaches to emancipation such as those concerned with freeing workers from oppressive labor conditions [1, p. 433]. By creatively applying theories of emancipation to understanding of IS, researchers can discover ways to promote gradients of emancipation for users. Given that a state of complete emancipation is elusive [4], research aimed at promoting gradients of emancipation in all contexts contributes to the elusive but worthwhile goal of human emancipation.

Richard and Robinson [9] explain that there is no one definition of emancipation that IS scholars accept.
Many competing conceptualizations of emancipation have been proffered as shown in Table 1. Taken together, these conceptualizations inform a broad definition of emancipation as the overcoming of constraints in such a way that individuals may control their own destinies and generally go from a worse to a better state.

Oppression involves constraints on freedom that are "unjust or harmful or at least unfair for some subgroup" [3, p. 27]. These constraints may relate to one or more components of emancipation. For instance, in situations of oppression related to cognitive control, constraint on an individual's freedom of thought is most relevant. Critical researchers warn that until the "structure of emancipation is better understood, attempts to emancipate may not achieve their ends" [10, p. 140]. For this reason, identifying relevant components of emancipation is key to the goal of promoting gradients of emancipation through IS.

\begin{tabular}{|c|c|}
\hline Reference & Emancipation Conceptualization \\
\hline [11] & $\begin{array}{l}\text { The emancipatory ideal contains the "possibility of freeing individuals from oppressive and } \\
\text { unwarranted expressions of power" (p. 62). }\end{array}$ \\
\hline [1] & $\begin{array}{l}\text { "Emancipation describes the process through which individuals and groups become freed from } \\
\text { repressive social and ideological conditions, in particular those that place socially unnecessary } \\
\text { restrictions upon the development and articulation of human consciousness" (p. 432). }\end{array}$ \\
\hline [12] & $\begin{array}{l}\text { Emancipators are those who "critique and transform both the status quo and their own fallible } \\
\text { beliefs" (p. 482). }\end{array}$ \\
\hline [13] & $\begin{array}{l}\text { "Any approach that claims an emancipatory intent should be able to promote participation and take } \\
\text { account of unequal power relations" (p. 50). }\end{array}$ \\
\hline [14] & $\begin{array}{l}\text { "Critical IS research specifically opposes technological determinism and instrumental rationality } \\
\text { underlying IS development and seeks emancipation from unrecognized forms of domination and } \\
\text { control enabled or supported by information systems" (p. 19). }\end{array}$ \\
\hline [2] & $\begin{array}{l}\text { An interest in emancipation guides critical researchers "in pursuit of freedom from any sort of } \\
\text { dogmatism" (p. 452). }\end{array}$ \\
\hline [15] & $\begin{array}{l}\text { Organizational emancipation is "the establishment of social conditions, which encourage } \\
\text { effectiveness through organizational democracy, specifically overcoming existing forms of } \\
\text { authoritarianism and social control if they perpetuate inequities of the status quo in the workplace" (p. } \\
\text { 85). }\end{array}$ \\
\hline [16] & $\begin{array}{l}\text { Emancipation entails "freeing individuals from power relations around which social and } \\
\text { organizational life are woven" (p. 196-197). }\end{array}$ \\
\hline [17] & $\begin{array}{l}\text { Oppression occurs when the "exercise of power in the social process" prevents openness and freedom } \\
\text { in interactions. "Human beings have therefore an "emancipatory interest' in freeing themselves from } \\
\text { constraints imposed by power relations" to attain emancipation, i.e., "to control their own destiny" (p. } \\
\text { 89). }\end{array}$ \\
\hline [18] & $\begin{array}{l}\text { Emancipation is a theoretical state where power dynamics are neutral or equal. Oppression is a } \\
\text { theoretical state where power dynamics are marginalizing or lead to domination. Practical states tend } \\
\text { to fall somewhere in between, and gradients of emancipation are worth striving for. Oppression } \\
\text { constrains freedom to think, act and belong. Emancipation balances freedom and authority. }\end{array}$ \\
\hline
\end{tabular}




\begin{tabular}{|c|c|}
\hline [19] & $\begin{array}{l}\text { "Emancipation is the overcoming of unwarranted constraints and the freeing of the mind (human } \\
\text { reason) from tutelage" (p. 171). "Emancipation means that more people can achieve their potential to } \\
\text { a greater degree" (p. 168). }\end{array}$ \\
\hline [20] & $\begin{array}{l}\text { Information systems can be designed to not only increase efficiency for the organization but also } \\
\text { "increase human understanding and emancipate people from undesirable social and physical } \\
\text { constraints, distorted communication and misapplied power" (p. 207). Not everyone seeks } \\
\text { emancipation because emancipation comes at a cost. }\end{array}$ \\
\hline [3] & $\begin{array}{l}\text { Emancipation requires that one takes issue with some oppressive human conditions or practices and } \\
\text { enlightens people as to their real situation. }\end{array}$ \\
\hline [21] & $\begin{array}{l}\text { The emancipatory (enlightenment) tradition of discourse ethics "values rationality and reason as ways } \\
\text { of determining moral action..." (p. 846). }\end{array}$ \\
\hline [22] & $\begin{array}{l}\text { Emancipatory knowledge interests stem from the human desire to be free from physical and mental } \\
\text { constraints and distortions. Emancipatory knowledge interests produce freedom and norms of justice } \\
\text { rooted in dialectic rationality. }\end{array}$ \\
\hline [23] & $\begin{array}{l}\text { Barriers to emancipation include "ideology (distorted communication), power, psychological } \\
\text { compulsions, and social constraint" (p. 542). }\end{array}$ \\
\hline [9] & $\begin{array}{l}\text { Emancipation is the "lynchpin" of critical research in IS, but there is "no clear acceptance" of a } \\
\text { definition of emancipation (p. 262). }\end{array}$ \\
\hline [24] & $\begin{array}{l}\text { Progressive emancipation, recovery of integrative values, reformation of social order and the claiming } \\
\text { of space for lost voices are possible outcomes of the four scientific discourses. }\end{array}$ \\
\hline [25] & Emancipation entails "allowing people to fulfill their potential" (p. 255). \\
\hline [26] & Open communication "is the first step toward emancipation" (p. 172). \\
\hline [27] & The status quo is unjust, but emancipation allows individuals to more fully achieve their potential. \\
\hline [28] & The primary goal of emancipation is for individuals or organizations to reach their full potential. \\
\hline [29] & $\begin{array}{l}\text { The status quo is "imperfect or unjust" and therefore requires emancipation, which is achieved through } \\
\text { the process of individuals sharing their insights and learning from others' insights (p. 2). }\end{array}$ \\
\hline [30] & $\begin{array}{l}\text { All social relationships are about power and where there is power there will be a struggle. } \\
\text { Technologies are not innately oppressive, but technologies are dangerous given that technologies are } \\
\text { tools of power. }\end{array}$ \\
\hline
\end{tabular}

\section{Method}

To identify relevant empirical papers, we followed the hermeneutic approach for conducting literature reviews [7]. In critical theories, the hermeneutic circle describes a process of understanding involving circular movements between consideration of a part (e.g., one paper) and a whole (e.g., one literature stream). The hermeneutic approach for conducting literature reviews involves iterative engagement with two circular processes, i.e., "search and acquisition" and "analysis and interpretation" [7, p. 264]. The search and acquisition process involved the search terms "emancipation + information systems", "liberation + information systems", "hegemony + information systems" and "oppression + information systems". The following resources were used: the AIS Senior Scholars' Basket of Journals, the AIS electronic library (journals only, publication dates 01/01/2000 to present, collected June 18, 2019), ProQuest ABI (English language only), Web of Science and Google Scholar (first five pages returned). This process gleaned 232 unique papers.

The analysis and interpretation process involved reviewing the papers and identifying relevant research.
Upon scanning the papers, we deemed 24 to be unrelated to our topic. Most of these unrelated papers featured the search terms in the reference section but not the main text. The remaining 208 papers were classified as empirical (102), theory/review (86), commentaries/editorials/debates (18), methods (1), or non-academic (1). Workshop reports and extended abstracts summarizing empirical research were classified as empirical.

Reading the 102 empirical papers allowed us to identify 46 highly relevant papers. These papers draw on critical theories, address a contemporary IS phenomenon, and articulate a contribution to the literature on emancipation in IS. As we read, our familiarity with the authors, journals and conferences publishing relevant research grew. Based on this familiarity, we searched for more papers from these sources [7], resulting in the addition of nine papers. We iteratively considered how the papers, together, form a body of research, and reinterpreted the papers to understand the importance of each within the body of research. Table 2 describes the 55 highly relevant empirical studies we used for our analysis. 


\begin{tabular}{|c|c|}
\hline Reference & Key Takeaway \\
\hline [31] & Explains how organizational boundaries can reinforce hegemonic power in offshoring relationships \\
\hline [32] & $\begin{array}{l}\text { Challenges the notion that expert systems which assume knowledge is universally understood can be } \\
\text { emancipatory }\end{array}$ \\
\hline [33] & Develops a context-specific notion of rationality in IS innovation \\
\hline [34] & Explains that African and Western views of technology and emancipation differ \\
\hline [35] & Describes the hegemonic effects of the digital divide and the challenges of Internet governance \\
\hline [36] & Explains how ICTs influence freedom throughout the world \\
\hline [37] & Proposes use of the rationality framework for critical examination of the use of IS in organizations \\
\hline [38] & $\begin{array}{l}\text { Explains how colonized IS research methods can oppress and calls for interdisciplinary research into } \\
\text { issues of marginalization and oppression }\end{array}$ \\
\hline [39] & Describes how emancipation of political will spurred development of smart cities \\
\hline [40] & Conceptualizes emancipation as the epicenter of the field of IS \\
\hline [41] & Finds ETHICS to be a suitable methodology to advance emancipation ideals \\
\hline [42] & Uses communicative action theory to show how virtual groups challenge and resolve validity claims \\
\hline [43] & Critiques the notion that ICTs are emancipatory rather than repressive \\
\hline [44] & $\begin{array}{l}\text { Explains that technology design always contains bias, resulting in a net advantage for the dominant } \\
\text { hegemony }\end{array}$ \\
\hline [45] & $\begin{array}{l}\text { Shows how labor structures in online games maintain hegemonic power of developers who control } \\
\text { the economic system }\end{array}$ \\
\hline [46] & Explores the emancipatory potential of Wikipedia design \\
\hline [47] & Presents evidence that technologies are used as tools of oppression in developing \\
\hline [48] & Asserts that new features can emancipate both users and the technology \\
\hline [49] & Explains how the totality of relations can lead to discrimination against women in IS \\
\hline [50] & Identifies practices that promote or inhibit emancipation in online health $\mathrm{cc}$ \\
\hline [51] & Calls for research on emancipation and IS design \\
\hline [52] & Challenges oppressive norms and definitions of ERP success \\
\hline [53] & Rejects techno-centric and economic impact measurements for st \\
\hline [54] & Demonstrates how datafication practices reproduce human solidarity \\
\hline [55] & Addresses the challenge of creating agency \\
\hline [56] & Argues that a researcher must first be emancipated to aid in the \\
\hline [57] & $\begin{array}{l}\text { Explains how ICT4D researchers can be more culturally sensitive to identify the emancipatory } \\
\text { interests of those they seek to help }\end{array}$ \\
\hline [58] & Describes social impacts of ICT and the digital divide \\
\hline [59] & Reveals mixed effects of ICTs on socioeconomic and $s$ \\
\hline [60] & Describes how new media empower the struggle against hegemonic regimes \\
\hline [61] & Expands knowledge of men's gendered experiences with IS \\
\hline [62] & Redefines an "emancipatory" ICT4D project as oppressive \\
\hline [63] & Uses Habermasian theories to challenge narrc \\
\hline [64] & $\begin{array}{l}\text { Describes the potential of online social networks to engage citizens and mobilize against oppressive } \\
\text { regimes }\end{array}$ \\
\hline [5] & Reveals digital media affordances for emancipation and hegemony in public discourse \\
\hline [65] & Exposes barriers to Internet access for people with disabilities \\
\hline [66] & $\begin{array}{l}\text { Attends to the matter of emancipating "organizational actors from false or unwarranted beliefs, } \\
\text { assumptions, and constraints" (p. 151) }\end{array}$ \\
\hline [67] & Critiques the practice of having people occupy a subservient role to technology \\
\hline [68] & $\begin{array}{l}\text { Outlines ways ICTs have been used for oppression/marginalization and/or emancipation/inclusion in } \\
\text { a digital activism context }\end{array}$ \\
\hline [69] & Reveals differences in perceptions of men and women in a work environment \\
\hline [70] & $\begin{array}{l}\text { Explains that ERPs may bring emancipatory transformation, or may be used as tools of oppression by } \\
\text { upper management }\end{array}$ \\
\hline [71] & a system can emancipate users to communicate their needs \\
\hline
\end{tabular}




\begin{tabular}{|l|l|}
\hline$[72]$ & Explores the emancipatory potential and realities of ICTs in Egypt \\
\hline$[73]$ & Critiques lack of advice in security policies about how workers should discharge responsibilities \\
\hline$[74]$ & $\begin{array}{l}\text { Reveals how local realities prevent individuals from exploiting the emancipatory potentials of } \\
\text { decision support systems }\end{array}$ \\
\hline$[75]$ & Challenges the conclusion that ICTs are emancipatory \\
\hline$[76]$ & Explains the tension IT managers experience between empowering workers and imposing IS tools \\
\hline$[77]$ & Demonstrates how Malaysians can use social media for self-emancipation \\
\hline$[78]$ & $\begin{array}{l}\text { Explains that IS emancipate by providing workers with information they need, but oppress through } \\
\text { deception so that workers have time to process the information }\end{array}$ \\
\hline$[4]$ & $\begin{array}{l}\text { Challenges prevailing practices in ICT for economic development projects and outlines practices for } \\
\text { using ICTs for human development and emancipation }\end{array}$ \\
\hline$[79]$ & $\begin{array}{l}\text { Explains how knowledge management systems capabilities free and constrain knowledge sharing } \\
\text { Uses the information systems theory of human-machine task allocation and an emancipatory theory } \\
\text { of humanization to challenge the treatment of students like machines }\end{array}$ \\
\hline$[80]$ & $\begin{array}{l}\text { Explains how theories of emancipatory pedagogy can guide marginalized groups seeking to use ICTs } \\
\text { for self-emancipation without unintentionally oppressing others }\end{array}$ \\
\hline$[81]$ & $\begin{array}{l}\text { Raises questions about how cultural messages embedded in Web documents distort communication } \\
\text { Challenges the notion that digital algorithms are omnipresent and hegemonic with evidence of } \\
\text { porousness and hackability }\end{array}$ \\
\hline$[82]$ &
\end{tabular}

Once relevant papers are identified, there are many ways literature can be classified [7]. Concept-centric classification supports understanding of concepts and relationships between concepts [84], as is an objective of this research. The first two authors worked independently to classify papers according to the component(s) of emancipation addressed. These two authors discussed their classifications and converged upon the following concept categories: agency, dialogue, inclusion, and rationality. Although these four categories may not be exhaustive, they do represent active research citing emancipatory theories in IS. Table 3 relates each concept to a component of emancipation and salient IS phenomena.

\begin{tabular}{|l|l|l|}
\hline \multicolumn{3}{|l|}{ Table 3. Components of Emancipation in the Sampled Literature } \\
\hline Relevant Concept & $\begin{array}{l}\text { Component of } \\
\text { Emancipation }\end{array}$ & IS Phenomena \\
\hline Agency & Freedom to act & $\begin{array}{l}\text { Systems subverting human users, computer-mediated control of } \\
\text { workers, behavioral control, punishment from surveillance }\end{array}$ \\
\hline Dialogue & $\begin{array}{l}\text { Freedom to } \\
\text { express }\end{array}$ & $\begin{array}{l}\text { Democratization of discourse, truth exposure, ideal speech, creative } \\
\text { expression, voice-giving }\end{array}$ \\
\hline Inclusion & $\begin{array}{l}\text { Freedom to } \\
\text { belong }\end{array}$ & $\begin{array}{l}\text { Inclusion of marginalized groups, economic inclusion, political } \\
\text { inclusion, ICT4D, digital divide }\end{array}$ \\
\hline Rationality & $\begin{array}{l}\text { Freedom to } \\
\text { think }\end{array}$ & $\begin{array}{l}\text { Constrained rationality, ideological control, distorted frames of } \\
\text { meaning, manipulation, bias }\end{array}$ \\
\hline
\end{tabular}

\section{Discussion}

We identified four components of emancipation relevant to emancipation research in IS. First, critical research on agency in IS relates to users' freedom to act. As technologies become more autonomous, practitioners and scholars warn of increasing threats to users' autonomy and agency. A dominant theme in this stream of emancipation research relates to when and how IS design affects users' abilities to exert agency and accomplish their goals [25, 27, 28, 55, 85]. Another theme relates to IS use for domination of workers through surveillance-enforced punishment systems and other forms of computer-mediated control $[45,67,70$, 76].

Second, critical research on dialogue in IS relates to users' freedom of expression. This stream of research explains how design of IS can foster ideal speech situations and support emancipatory discourse. Much of this research builds on Habermasian theories [22, 42, 46, 82], though not all [24]. This stream of research highlights the role of design in shaping socio-technical systems and altering the nature of interpersonal communication. Research on broadcast communication explores the societal effects of digital media affordances for public discourse [5]. Other research in this vein 
questions dominant thinking about the role of IS in the development of a "new information hegemony" at the societal level [86, p. 461].

Third, critical research on inclusion in IS has multiple, diverse streams. One stream examines how design and governance of IS can promote social inclusion of marginalized individuals and groups $[4,68$, 80, 81, 87]. Another stream focuses on bridging the digital divide [35, 56, 88]. Much inclusion research studies how to bring IS and associated economic and social benefits to users in developing countries and rural areas $[62,89]$. Inclusion of marginalized individuals and groups in the research process is also a concern of IS researchers [90].

Finally, critical research on rationality in IS discusses ways system design and use shape users' consciousness. This stream of research seeks to explain how design shapes users' interpretations of meaning. Research sheds light on how broad, ubiquitous systems hide or present information in ways that alter users' cognitions and may prevent the development of robust, emancipatory rationalities [1, 32, 63, 68]. Relatively little is known about the effects of systems design on the development of collective meaning or ideologies at the societal level [5].

In summary, the concepts of agency, dialogue, inclusion, and rationality each relate to a component of emancipation. These concepts are pertinent to the study of emancipation at the individual, group, organizational, and societal levels. Empirical research in IS contributes to understanding of how gradients of emancipation can be achieved in specific contexts. The lack of an established typology of emancipation components inhibits generalizability and integration of these research streams.

\section{An Agenda for Future Research}

An important outcome of specific theorizing literature reviews is the identification of gaps in understanding and the development of an agenda for future research [6]. To this end, we now discuss opportunities for future research related to the four components of emancipation.

Agency: There is a vast body of IS literature about how users evaluate IS in terms of ease of use and usefulness to implement these systems for efficiency [91-93]. But might intelligent systems someday evaluate humans in terms of ease of use and usefulness, and "implement" workers or users for efficiency? Management scholars are already using adaptive algorithms to determine work team membership and assigning work tasks based on individual traits [94]. Although science fiction authors have considered this possibility for some time, the sophistication of new systems requires IS scholars also address these issues. How real is this threat? What strategies do users employ to avoid system-enforced control, and what are the unintended effects?

Dialogue: Promoting rational discourse is an important goal of any civilization. Systems may foster emancipatory discourse by facilitating creative expression, truth exposure, the surfacing of diverse perspectives, democratization, and sincere inputs $[5,24$, 46], or, content restrictions and structural constraints of systems may inhibit these goals [5]. Although foundational research in this area examines design, future research should consider the socio-technical systems at a meta-level to understand how governance can enhance the emancipatory effects of design. What types of governance promote emancipatory dialogue? How can governance processes balance the need for freedom and accountability in dialogue? At what point do governance mechanisms designed for emancipation become oppressive?

Inclusion: Efforts to address the digital divide have focused on ICTs for development projects [53], accessible design of IS [88], and the inclusion of marginalized individuals in IT professions [49, 69]. Critical theories provide a means of critiquing inclusion initiatives and explaining unintended consequences. Critical theories also provide normative guidance for how to promote inclusion. How may IS be leveraged to identify marginalization and promote inclusion? Levels issues complicate inclusion research. How does inclusion at the individual level affect group outcomes and vice versa? How can inclusion be fostered at multiple levels of analysis? What role should organizations and platform owners play in promoting inclusion?

Rationality: Decision support systems and related technologies free users to focus on more important aspects of work by evaluating measurable criteria and recommending actions. These systems are designed to allow users to make decisions with less cognitive effort. Yet, in doing so, these systems reduce users' consciousness of how decisions are made [78]. How do users decide what decisions to outsource to IS? What kinds of information should users engage with and what kinds of information are fine to ignore? This issue is salient in this era of black-boxed machine learning that prevents some information from being shared with users. Another area where constrained consciousness is a growing problem is fake news on social media. It is often difficult for users to distinguish between fact and fiction online, due in part to the role of news feed algorithms that recommend content to optimize engagement rather than truth exposure. How can users tell whether their cognitions are being suppressed? What new technologies are needed to aid users in navigating 
oppressive information environments and avoiding cognitive overload or thought control by systems developers and platform owners?

In addition to research related to the four components of emancipation, future IS research should consider foundational and philosophical questions about emancipation. Prior research describes the portable design of a new technology such that it can be used outside of a physical office space as the emancipation of that technology [48]. Notably, design may relieve a system of constraints and unleash the system's full potential. But, can technologies be emancipated? Or, is emancipation a strictly human phenomenon? Can technologies oppress? Or, do humans oppress other humans using technologies? Another area of debate relates to the appropriateness of applying theories of emancipation in innocuous contexts. Should theories of emancipation be applied only to situations of stark oppression? Or, should gradients of emancipation be pursued in innocuous contexts also?

The typology of emancipation components developed through this research provide the foundation for future work reviewing and synthesizing insights from these streams of research. Such an effort is needed to build a cumulative tradition of emancipation research in IS. Moving forward, future research should vet and refine the classification of emancipation components outlined herein. Researchers can take advantage of the insights of experts fighting for freedom such as NGO leaders and activists by using focus groups as described by Rosemann and Vessey [95]. Such an effort will move the IS field forward toward a richer understanding of how IS can promote emancipation.

\section{Conclusion}

This research identifies four components of emancipation studied in the IS literature. Doing so ties together seemingly disparate streams of IS literature so that future research may more closely examine and integrate these streams. Although researchers can and do draw on these literatures without referencing the meta-theories of emancipation that inform their research, linking individual studies to meta-theories is essential to the establishment of a tradition of cumulative research in this area. Hooking into metatheories allows researchers to position their research prominently in the tapestry of emancipation research in IS so that connections may be drawn, and patterns may be revealed across studies. We therefore call for future research on agency, dialogue, inclusion, and rationality that contributes to the growing body of work on emancipation in IS.

\section{References}

[1] Alvesson, M., and H. Willmott, "On the Idea of Emancipation in Management and Organization Studies," Academy of Management Review, vol. 17, no. 3, pp. 432-464, 1992.

[2] Cecez-Kecmanovic, D., "Doing Critical Information Systems Research-Arguments for A Critical Research methodology," European Journal of Information Systems, vol. 20, no. 4, pp. 440-455, 2011.

[3] Myers, M.D., and H.K. Klein, "A Set of Principles for Conducting Critical Research in Information Systems, "MIS Quarterly, vol. 35, no. 1, pp. 17-36, 2011.

[4] Young A.G., "Using ICT for Social Good: Cultural Identity Restoration through Emancipatory Pedagogy," Information Systems Journal, vol. 28, no. 2, pp. 340-358, 2018.

[5] Miranda S.M., A. Young, and E. Yetgin, "Are Social Media Emancipatory or Hegemonic? Societal Effects of Mass Media digitization in the Case of the SOPA Discourse," MIS Quarterly, vol. 40, no. 2, pp. 303-329, 2016.

[6] Leidner D.E., "Review and Theory Symbiosis: An Introspective Retrospective," Journal of the Association for Information Systems, vol. 19, no. 6, pp. 552-567, 2018.

[7] Boell, S.K., and D. Cecez-Kecmanovic, "A Hermeneutic Approach for Conducting Literature Reviews and Literature Searches," Communications of the Association for Information Systems, vol. 34, pp. 257-286, 2014.

[8] Alvesson, M., and H. Willmott, "On the Idea of Emancipation in Management and Organization Studies ," Academy of Management Review, vol. 17, no. 3, pp. 432-464, 1992.

[9] Richardson H., and B. Robinson, "The Mysterious Case of the Missing Paradigm: A Review of Critical Information Systems Research 1991-2001," Information Systems Journal, vol. 17, no. 3, pp. 251$270,2007$.

[10] Adam, A., "Gender, Emancipation and Critical Information Systems," ECIS 2001 Proceedings, pp. 139147, 2001.

[11] Adam, A., "Exploring the Gender question in critical information systems," Journal of Information Technology, vol. 17, no. 2, pp. 59-67, 2002.

[12] Basden, A., "Enabling A Kleinian Integration of Interpretivist and Socio-critical IS Research: The Contribution of Dooyeweerd's Philosophy," European Journal of Information Systems, vol. 20, no.4, pp. 477489, 2011.

[13] Brooke, C., "What Does It Mean to Be 'Critical' in IS Research?" Journal of Information Technology, vol. 17, no. 2, pp. 49-57, 2002.

[14] Cecez-Kecmanovic, D., "Basic Assumptions of the Critical Research Perspectives in Information Systems , Handbook of Critical Information Systems Research: Theory and Application, pp. 19-46, 2005.

[15] Hirschheim, R., and H.K. Klein, "Realizing Emancipatory Principles in Information Systems 
Development: The Case for ETHICS," MIS Quarterly, vol. 18, no. 1, pp. 83-109, 1994.

[16] Howcroft, D., and E.M. Trauth, "The Choice of Critical Information Systems Research," Information Systems Research, pp. 195-211, 2004.

[17] Jackson, M.C., "An Integrated Programme for Critical Thinking in Information Systems Research," Information Systems Journal, vol. 2, no. 2, pp. 83-95, 1992.

[18] Kane, G., Young, A., Majchrzak, and S. Ransbotham. "Avoiding an Oppressive Future of Machine Learning: A Design Theory for Emancipatory Assistants," MIS Quarterly, forthcoming.

[19] Klein, H.K., and M.Q. Huynh, "The Critical Social Theory of Jürgen Habermas and Its Implications for IS Research," Social Theory and Philosophy for Information Systems, pp. 157-237, 2004.

[20] Lyytinen, K.J., and H.K. Klein, "The Critical Theory of Jürgen Habermas as a Basis for A Theory of Information Systems," Research Methods in Information Systems, pp. 207-225, 1985.

[21] Mingers, J., and G. Walsham, "Toward Ethical Information Systems: The Contribution of Discourse Ethics," MIS Quarterly, vol. 34, no. 4, pp. 833-854, 2010.

[22] Ngwenyama, O.K., "The Critical Social Theory Approach to Information Systems: Problems and Challenges," Information Systems Research: Contemporary Approaches and Emergent Traditions, pp. 267-280, 1991.

[23] Porra, J., R. Hirschheim, and M.S. Parks, "The Historical Research Method and Information Systems Research," Journal of the Association for Information Systems, vol. 15, no. 9, pp. 536-576, 2014.

[24] Schultze, U., and D.E. Leidner, "Studying Knowledge Management in Information Systems Research: Discourses and Theoretical Assumptions," MIS Quarterly, vol. 26, no. 3, pp. 213-242, 2002.

[25] Shaw, M.C., and B.C. Stahl, "On Quality and Communication: The Relevance of Critical Theory to Health Informatics," Journal of the Association for Information Systems, vol. 12, no. 3, pp. 255-273, 2011.

[26] Silva, L., "Epistemological and Theoretical Challenges for Studying Power and Politics in Information Systems," Information Systems Journal, vol. 17, no. 2, pp. 165-183, 2007.

[27] Stahl, B.C., "ETHICS, Morality and Critique: An Essay on Enid Mumford's Socio-Technical Approach," Journal of the Association for Information Systems, vol. 8, no. 9, pp. 479-490, 2007.

[28] Stahl, B.C., "The Ethical Nature of Critical Research in Information Systems," Information Systems Journal, vol. 18, no. 2, pp. 137-163, 2008.

[29] Stahl, B.C., M.C. Tremblay, and C.M. LeRouge, "Focus Groups and Critical Social IS Research: How the Choice of Method Can Promote Emancipation of Respondents and Researchers," European Journal of Information Systems, vol. 20, no. 4, pp. 378-394, 2011.

[30] Willcocks, L., "Foucault, Power/Knowledge and Information Systems: Reconstructing the Present,"
Social Theory and Philosophy for Information Systems, pp. 238-296, 2004.

[31] Abbott, P., Y. Zheng, R. Du, and L. Willcocks, "From Boundary Spanning to Creolization: A Study of Chinese Software and Services Outsourcing Vendors," The Journal of Strategic Information Systems, vol. 22, no. 2, pp. 121-136, 2013.

[32] Adam, A., and H. Richardson, "Feminist Philosophy and Information Systems," Information Systems Frontiers, vol. 3, no. 2, pp. 143-154, 2001.

[33] Avgerou, C., and K. McGrath, "Power, Rationality, and the Art of Living through Socio-Technical Change," MIS Quarterly, vol. 31, no. 2, pp. 295-315, 2007.

[34] Bidwell, N.J., "Moving the Centre to Design Social Media in Rural Africa," AI \& Society, vol. 31, no. 1, pp. 51-77, 2016.

[35] Brousseau, E., and K.L. Kraemer, "Globalization and eCommerce III. The French Environment and Policy," Communications of the Association for Information Systems, vol. 10, pp. 73-128, 2003.

[36] Carlsson, U., "Freedom of Expression in the Digital Transition," Journal of Media Business Studies, vol. 13, no. 3, pp. 187-197, 2016.

[37] Cecez-Kecmanovic, D., M. Janson, and A. Brown, "The Rationality Framework for A Critical Study of Information Systems," Journal of Information Technology, vol. 17, no. 4, pp. 215-227, 2002.

[38] Chughtai, H., M.D. Myers, Young, A. T. Borsa, V. Cardo, O. Demirkol, ... \& E. Young, "Demarginalizing Interdisciplinarity in IS Research: Interdisciplinary Research in Marginalization," Communications of the Association for Information Systems, 2020.

[39] Das, D.K., "Exploring the Politico-Cultural Dimensions for Development of Smart Cities in India," International Review for Spatial Planning and Sustainable Development, vol. 5, no. 3, pp. 79-99, 2017.

[40] Desouza, K.C., P. Ein-Dor, D.J. McCubbrey, R.D. Galliers, M.D. Myers, and R.T. Watson, "Social Activism in Information Systems Research: Making the World A Better Place," Communications of the Association for Information Systems, vol. 19, no. 1, pp. 261-277, 2007.

[41] Elbanna, A., and M. Newman, "The Rise and Decline of the ETHICS Methodology of Systems Implementation: Lessons for IS Research," Journal of Information Technology, vol. 28, no. 2, pp. 124-136, 2013.

[42] Germonprez, M., and I. Zigurs, "Task, Technology, and Tailoring in Communicative Action: An in-Depth Analysis of Group Communication," Information and Organization, vol. 19, no. 1, pp. 22-46, 2009.

[43] Golkar, S., "Liberation or Suppression Technologies? The Internet, the Green Movement and the Regime in Iran," International Journal of Emerging Technologies and Society, vol. 9, no. 1, pp. 50-70, 2001.

[44] Goodspeed, R., "Digital Knowledge Technologies in Planning Practice: From Black Boxes to Media for Collaborative Inquiry," Planning Theory \& Practice, vol. 17, no. 4, pp. 577-600, 2016.

[45] Greenhill, A., and G. Fletcher, "Laboring Online: Are There 'New' Labor Processes in Virtual Game 
Worlds?" Journal of the Association for Information Systems, vol. 14, no. 11, pp. 672-693, 2013.

[46] Hansen, S., N. Berente, and K. Lyytinen, "Wikipedia, Critical Social Theory, and the Possibility of Rational Discourse," The Information Society, vol. 25, no. 1, pp. 38-59, 2009.

[47] Heeks, R., "Information Systems and Developing Countries: Failure, Success, and Local Improvisations, "The Information Society, vol. 18, no. 2, pp. 101-112, 2002.

[48] Hellman, R., "Emancipation of and by ComputerSupported Cooperative Work," Scandinavian Journal of Information Systems, vol. 1, no. 1, pp. 143-161, 1989.

[49] Howcroft, D., and E.M. Trauth, "The Implications of A Critical Agenda in Gender and IS Research," Information Systems Journal, vol. 18, no. 2, pp. 185202, 2008.

[50] Hur, I., K.C. Cousins, and B.C. Stahl, "A Critical Perspective of Engagement in Online Health Communities," European Journal of Information Systems, vol. 28, no. 5, pp. 523-548, 2019.

[51] Iversen, O.S., A.M. Kanstrup, and M.G. Petersen, "A Visit to the 'New Utopia' Revitalizing Democracy, Emancipation and Quality in Co-operative Design," In Proceedings of the Third Nordic Conference on Human-Computer Interaction, pp. 171-179, 2004.

[52] Jahanyan, S., A. Azar, and H.D. Fard, “Utilizing Multi - Aspectual Understanding as A Framework for ERP Success Evaluation,” Journal of Enterprise Information Management, vol. 25, no. 5, pp. 479-504, 2012.

[53] Kanungo, S., "On the Emancipatory Role of Rural Information Systems," Information Technology \& People, vol. 17, no. 4, pp. 407-422, 2004.

[54] Kelly, S., and C. Noonan, "The Doing of Datafication (and What this Doing Does): Practices of Edification and the Enactment of New Forms of Sociality in the Indian Public Health Service," Journal of the Association for Information Systems, vol. 18, no. 12, pp. 872-899, 2017.

[55] Koch, S., "Collective Influence on Information Technology in Virtual Organizations-Emancipatory Management of Technology?" Technology Analysis \& Strategic Management, vol. 12, no. 3, pp. 357-368, 2000.

[56] Krauss, K., "Collisions between the Worldviews of International ICT Policy-Makers and A Deep Rural Community in South Africa: Assumptions, Interpretation, Implementation, and Reality," Information Technology for Development, vol. 19, no. 4, pp. 296-318, 2013.

[57] Krauss, K., and M. Turpin, "The Emancipation of the Researcher as Part of Information and Communication Technology for Development Work in Deep Rural South Africa," The Electronic Journal of Information Systems in Developing Countries, vol. 59, no. 1, pp. 121, 2013.

[58] Kvasny, L., and M. Keil, "The Challenges of Redressing the Digital Divide: A Tale of two US Cities," Information Systems Journal, vol. 16, no. 1, pp. 23-53, 2006.
[59] Lee, G.W., B. Shao, and A. Vinze, "The Role of ICT as A Double-Edged Sword in Fostering Societal Transformations," Journal of the Association for Information Systems, vol. 19, no. 3, pp. 209-246, 2018.

[60] Lee, P.S., C.Y. So, L. Leung, F.L. Lee, and M. Chan, "The Struggle for Hegemony: The Emergence of A Counter-Public Sphere in Post-1997 Hong Kong," Chinese Journal of Communication, vol. 10, no. 4, pp. 338-359, 2017.

[61] Light, B., "Introducing Masculinity Studies to Information Systems Research: The Case of Gaydar," European Journal of Information Systems, vol. 16, no. 5, pp. 658-665, 2007.

[62] Lin, C. I., Kuo, F., and M.D. Myers, "Extending ICT4D Studies: The Value of Critical Research," MIS Quarterly, vol. 39, no. 3, pp. 697-712, 2015.

[63] Lyytinen, K., and R. Hirschheim, "Information Systems as Rational Discourse: An Application of Habermas's Theory of Communicative Action," Scandinavian Journal of Management, Vol. 4, no. 1-2, pp. 19-30, 1988.

[64] McGrath, K., A. Elbanna, M. Hercheui, P. Panagiotopoulos, and E. Saad, "Exploring the Democratic Potential of Online Social Networking: The Scope and Limitations of e-Participation," Communications of the Association for Information Systems, vol. 30, no. 1, pp. 239-254, 2012.

[65] Newman, L., K. Browne - Yung, P. Raghavendra, D. Wood, and E. Grace, “Applying A Critical Approach to Investigate Barriers to Digital Inclusion and Online Social Networking among Young People with Disabilities," Information Systems Journal, vol. 27, no. 5, pp. 559-588, 2017.

[66] Ngwenyama, O.K., and A.S. Lee, "Communication Richness in Electronic Mail: Critical Social Theory and the Contextuality of Meaning," MIS Quarterly, vol. 21, no. 2, pp. 145-167, 1997.

[67] Oliver, D., and C. Romm, "Justifying Enterprise Resource Planning Adoption," Journal of Information Technology, vol. 17, no. 4, pp. 199-213, 2002.

[68] Ortiz, J., A. Young, M.D. Myers, R.T. Bedeley, D. Carbaugh, H. Chughtai, ... and E. Grimshaw, "Giving Voice to the Voiceless: The Use of Digital Technologies by Marginalized Groups," Communications of the Association for Information Systems, vol. 45, no. 1, 2019.

[69] Reid, M.F., M.W. Allen, D.J. Armstrong, and C.K. Riemenschneider, "Perspectives on Challenges Facing Women in IS: The Cognitive Gender Gap," European Journal of Information Systems, vol. 19, no. 5, pp. 526$539,2010$.

[70] Ripamonti, S.C., and L. Galuppo, "Work Transformation Following the Implementation of An ERP System," Journal of Workplace Learning, vol. 28, no. 4, pp. 206-223, 2016.

[71] Silsand, L., and G. Ellingsen, "Generification by Translation: Designing Generic Systems in Context of the Local," Journal of the Association for Information systems, vol. 15, no. 4, pp. 177-196, 2014.

[72] Stahl, B.C., N. McBride, and I. Elbeltagi, "Development and Emancipation: The Information Society and 
Decision Support Systems in Local Authorities in Egypt." Journal of Information, Communication and Ethics in Society, vol. 8, no. 1, pp. 85-107, 2010.

[73] Stahl, B.C., N.F. Doherty, and M. Shaw, "Information Security Policies in the UK Healthcare Sector: A Critical Evaluation,” Information Systems Journal, vol. 22, no. 1, pp. 77-94, 2012.

[74] Stahl, B.C., R. Heersmink, P. Goujon, C. Flick, J. Van Den Hoven, K. Wakunuma, ... and M. Rader, "Identifying the Ethics of Emerging Information and Communication Technologies: An Essay on Issues, Concepts and Method," International Journal of Technoethics, vol. 1, no. 4, pp. 20-38, 2010.

[75] Stein, E.A., "Are ICTs Democratizing Dictatorships? New Media and Mass Mobilization," Social Science Quarterly, vol. 98, no. 3, pp. 914-941, 2017.

[76] Trusson, C.R., N.F. Doherty, and D. Hislop, "Knowledge Sharing Using IT Service Management Tools: Conflicting Discourses and Incompatible Practices," Information Systems Journal, vol. 24, no. 4, pp. 347-371, 2014.

[77] Tye, M., C. Leong, F. Tan, B. Tan, and Y.H. Khoo, "Social Media for Empowerment in Social Movements: The Case of Malaysia's Grassroots Activism," Communications of the Association for Information Systems, vol. 42, no. 1, pp. 408-430, 2018.

[78] Vieira da Cunha, J., A. Carugati, and A. Leclercq Vandelannoitte, "The Dark Side of Computer Mediated Control," Information Systems Journal, vol. 25, no. 4, pp. 319-354, 2015.

[79] Young, M.L., F.Y. Kuo, and M.D. Myers, "To Share or Not to Share: A Critical Research Perspective on Knowledge Management Systems," European Journal of Information Systems, vol. 21, no. 5, pp. 496-511, 2012.

[80] Young, A., E. Young, and R.M. Farley, "The Hegemony of Treating Students Like Machines: Insights from Emancipatory Theories and Human-Machine Functions," Americas Conference on Information Systems, 2019.

[81] Young, E., and A. Young, “Cyberactivism as Emancipatory Pedagogy: The Case of the Five Tribes Freedmen," Americas Conference on Information Systems, 2019.

[82] Zahedi, F.M., W.V. Van Pelt, and M. Srite, "Web Documents' Cultural Masculinity and Femininity," Journal of Management Information Systems, vol. 23, no. 1, pp. 87-128, 2006.

[83] Zook, M., and M. Graham, "Hacking Code/Space: Confounding the Code of Global Capitalism," Transactions of the Institute of British Geographers, vol. 43, no. 3, pp. 390-404, 2018.

[84] Webster, J., and R.T. Watson, "Analyzing the Past to Prepare for the Future: Writing a Literature
Review,"MIS Quarterly, vol. 26, no. 2, pp. xiii-xxiii, 2002.

[85] Demetis, D., and A.S. Lee, "When Humans Using the IT Artifact Becomes IT Using the Human Artifact," Journal of the Association for Information Systems, vol. 19, no. 10, pp. 2018.

[86] Tremblay, G., "The Information Society: From Fordism to Gatesism: The 1995 Southam Lecture," Canadian Journal of Communication, vol. 20, no. 4, pp. 461-482, 1995.

[87] Cibangu, S.K., M. Hepworth, and D. Champion, "Mobile Phones for Development: An Information Case Study of Mobile Phone Kiosk Vendors in the Congo," Aslib Journal of Information Management, vol. 69, no. 3, pp. 294-315, 2017.

[88] George, J.J, and D.E. Leidner, "Why Marginalized Groups Struggle to Leverage Digital Activism," In Twenty-fourth Americas Conference on Information Systems, New Orleans, 2018.

[89] Díaz Andrade, A., and C. Urquhart, "Unveiling the Modernity Bias: A Critical Examination of the Politics of ICT4D," Information Technology for Development, vol. 18, no. 4, pp. 281-292, 2012.

[90] Myers, M.D., H. Chughtai, E. Davidson, P. Tsibolane, and A.G. Young, "Studying the Other or Becoming the Other: Engaging with Indigenous Peoples in IS Research," Communications of the Association for Information Systems, pp. 1-14, 2020.

[91] Venkatesh, V., and H. Bala, "Technology Acceptance Model 3 and a Research Agenda on Interventions," Decision Sciences, vol. 39, no. 2, pp. 273-315, 2008.

[92] Venkatesh, V., J.Y. Thong, and X. Xu, "Consumer Acceptance and Use of Information Technology: Extending the Unified Theory of Acceptance and Use of Technology," MIS Quarterly, vol. 36, no. 1, pp. 157$178,2012$.

[93] Venkatesh, V., M.G. Morris, G.B. Davis, and F.D. Davis, "User Acceptance of Information Technology: Toward a Unified View," MIS Quarterly, vol. 27, no. 3, pp. 425-478, 2003.

[94] Hollenbeck, J.R., P. Alexander, F. Cho, and R. Hemsley, "Team Composition and Artificial Intelligence: A Conceptual Model and Paradigm for the New Economy," Presented at International Management Conference, Ireland, 2018.

[95] Rosemann, M., and I. Vessey, "Toward Improving the Relevance of Information Systems Research to Practice: The Role of Applicability Checks," MIS Quarterly, vol. 32, no. 1, pp. 1-22, 2008. 